\title{
John Fox-Russell, VC MC, RAMC (1893-1917) A Forgotten Hero of Military Medicine
}

\author{
E Dolev \\ MD
}

Department of Internal Medicine " E", Wolfson Medical Center, Holon, and the Department of Behavioural Sciences, Sack $\overrightarrow{\bar{B}}$ ler School of Medicine, Tel Aviv University, Tel Aviv, Israel

SUMMARY: The chance finding of the grave of Captain John Fox-Russell, VC, MC in the British Militaa Cemetery in Beer Sheva, Israel led the author to research the life of this medical hero.

\section{Introduction}

At the end of a journey to the Beer Sheva, while studying the medical aspects of Allenby's Palestine Campaigns, I visited the British Military Cemetery for those who were killed in the area during these campaigns. What began as an aimless visit, soon became a search for RAMC servicemen who might be buried there. An hour later, I stood in front of a tombstone of Captain John FoxRussell, VC, MC (Fig 1) on which was written:

"He gave his life for others; greater love hath no man than this:

That was the moment when I began to walk in the footsteps of John Fox-Russell, one of my heroes in military medicine.

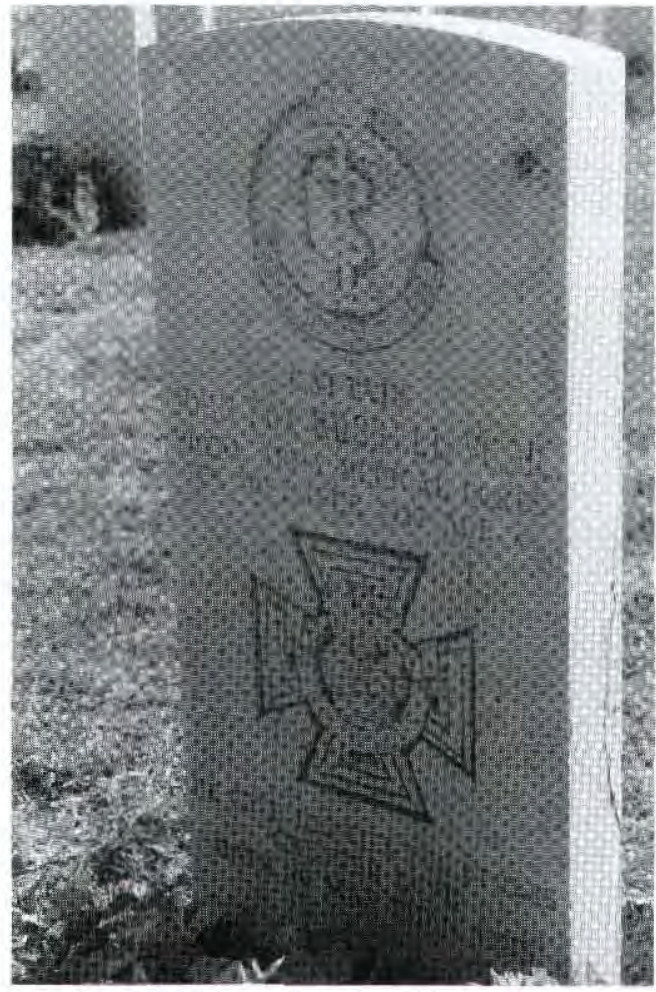

Fig 1. John Fox-Russell's tomb
The Victoria Cross (VC) is the highest recognition $\vec{\nabla}$ courage on the battlefield awarded in the British Empire During a whole century, 1845-1945, only 39 RAM members were awarded the $\mathrm{VC}$, apparently a very $\mathrm{sm}$ त्ञ number (1). In part, it may be explained by the inability $\overline{\mathrm{B}} \mathrm{f}$ non-medical combatants to judge the merits of medic? officers and medical orderlies who are engaged in th difficult, tedious and risky task of rescuing the lives $\Phi$ injured soldiers. Thus, to be a hero of military mediginu, one has to be a man of great virtues: dedicat市 $\vec{\Phi}$, excellence, devotion and courage.

John Fox-Russell is presented here as a unique exampte of a hero of military medicine, unfortunately c forgotten.

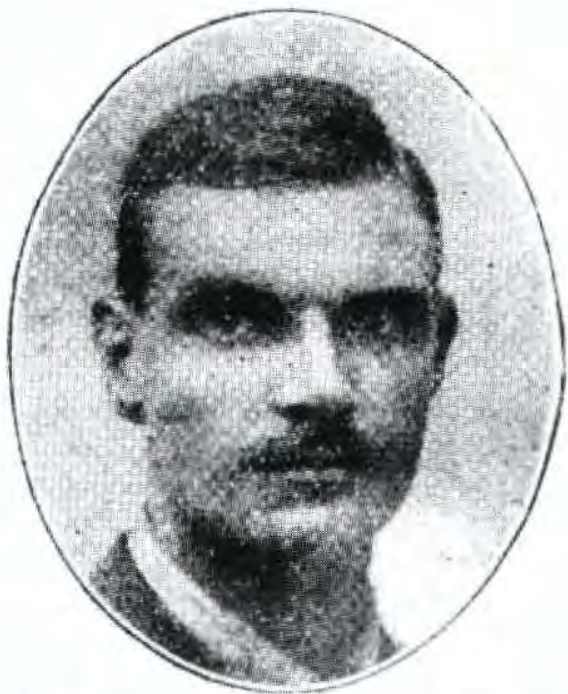

Fig 2. John Fox-Russell VC, MC, RAMC From The Lancet, Feb 2, 1918

\section{Biography}

John Fox-Russell (Fig 2), was born in Holyhead Anglesey, England, January 27th 1893 . He was the eldeg son of Dr \& Mrs Fox-Russell. He studied at Magdalco 
College Choir School, Oxford and St. Bees School. While at St. Bees, he joined the Cadet Force, showing great interest in military science. In 1909 John Fox-Russell became one of the youngest students ever to be accepted for medical studies into the Middlesex Hospital Medical School in London. While in medical school, he joined the
University of London Officers' Training Course and laters obtained a commission in the 6th (Caernarvonshire and Anglesey Territorial) battalion of the Royal Welsh Fusiliers (RWF).

Upon the outbreak of the War in 1914, John left his medical studies and joined his battalion as a $2 \mathrm{nd}$

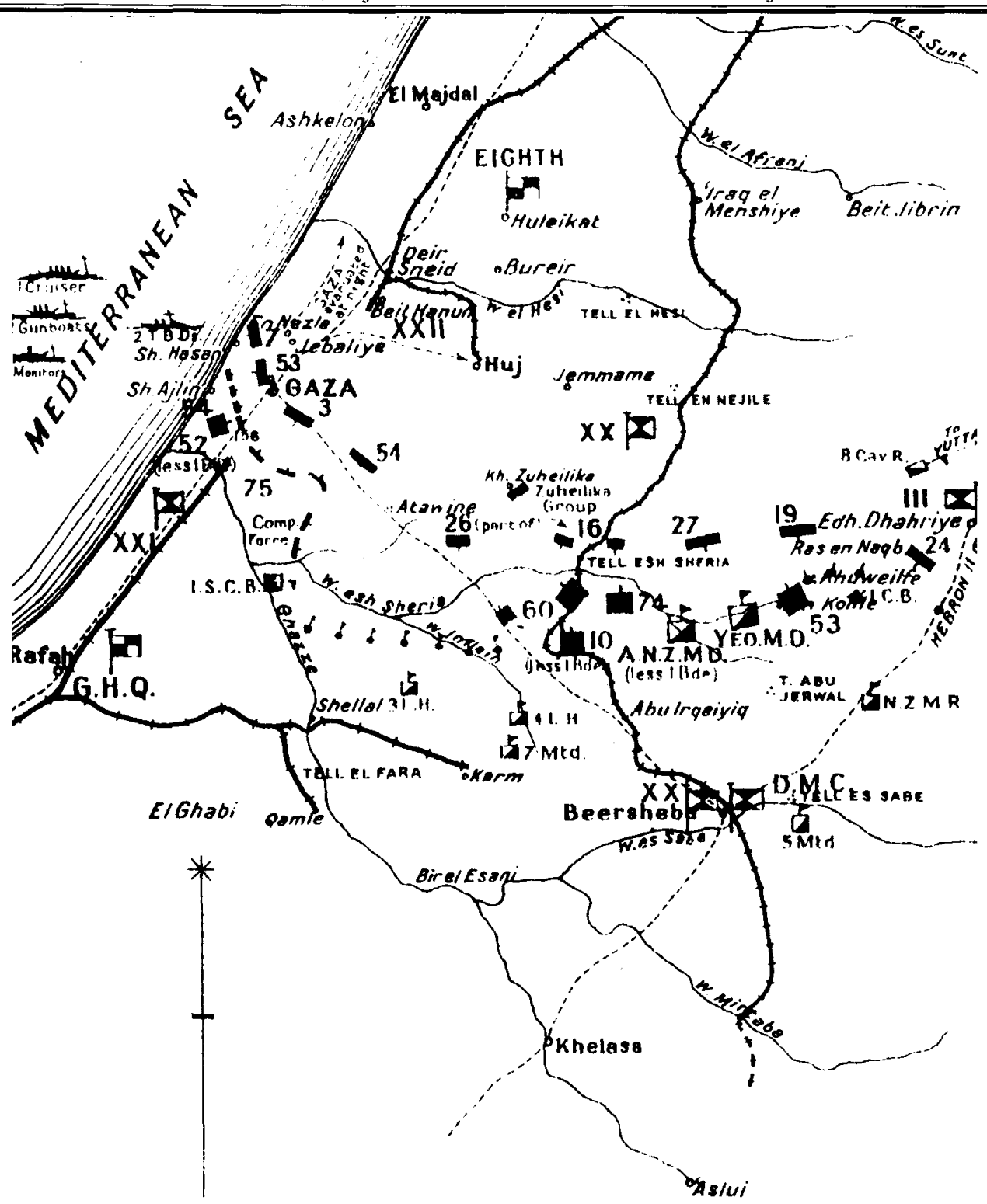

Situation at 6p.m. 6th Nov 1917

Scale of miles.

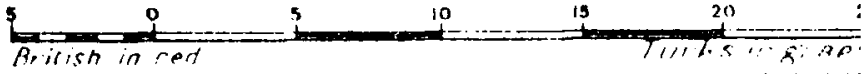

Fig 3. Map of the Third Battle of GAZA 
lieutenant. He was promoted on January 27th 1915 to Captain. After the first phase of the war, John Fox-Russell returned to the medical school, graduated, became MRCS and commissioned to the RAMC. First he was attached to a battery of Royal Field Artillery, but soon applied to be transferred to his old unit. When his request was granted, he joined the 6th RWF, a battalion in the 158th Infantry Brigade of the 53rd Welsh Division, then a part of the Egypt Expeditionary Force, becoming the medical officer of the battalion. On September 16th 1916, before leaving for Egypt, he married Alma Taylor of Tunbridge Wells, Kent $(2,3)$.

At the time when John Fox-Russell joined his old unit in Egypt, the British intention was to open a new front in the Middle East, as fighting in the European Western Front had come to a standstill.

On March 26th 1917, the British troops attacked for the first time the fortified town of Gaza. The 53rd Welsh Division, consisting of the 158th, 159th and 160th brigades, was a part of the offensive. The 6th RWF, FoxRussell's battalion, was one of the four battalions of the 158th.

The brigade was directed to Ali Muntar ridge, a hill overlooking the open plain. The battalions advanced under heavy fire, but at the bottom of the hill the forces encountered cactus hedges and progress became slow. From that time on, fighting continued with heavy casualties on both sides. At dusk, the efforts were successful: at 17:30 the Ali Muntar ridge was in British hands, but it was too late: General Dobbel, the Commander-in-Chief, decided due to misinformation, to withdraw. The British casualties during the first battle of Gaza were 523 killed, 2932 wounded and 512 missing.

Field Marshall Sir Archibald Wavell wrote in his "Palestine Campaigns": "Capture of Ali Muntar by the 53rd Division will bear comparison with the classic exploits of British Infantry. The approach was over bare ground against an enemy strongly posted and entrenched, with numerous machine guns and a powerful artillery. The enemy's main position was a difficult target. The hostile trenches were hard to detect. The last part of the assault was blind fighting uphill through cactus hedges against machine guns and riflemen. There was no shade and no water." (4)

Captain John Fox-Russell of the 6th RWF of the 158th brigade won the Military Cross (MC) "for conspicuous gallantry and devotion to duty. He showed the greatest courage and skill in collecting wounded men of all regiments and in dressing them under continuing shell and rifle fire."(5)

The second battle in Gaza was launched on April 17th 1917. Again there was no victory. In this battle, the 53rd Division fought on "Samson's Ridge" as a secondary force and could not make any deep impression in the Turkish defence. This time most of the casualties were in the 54th Division.

During June 1917, General Allenby became
Commander-in-Chief of the EEF. After assump command, General Allenby dedicated himself to the sefdy of the previous defeats in Gaza. He came to the conclusion that another direct attack on Gaza might a mistake, and the main thrust should be directed against Beer Sheva.

On October 31st 1917, the campaign known as ghthe Third Battle of Gaza was launched (Fig 3). The XX Coips which consisted of the 10th, 53rd, 60th and 74th Divisions attacked Beer Sheva. The attack was a resoun success, but in order to secure the advance to the Noth, the high ridge north of Beer Sheva had to be captufed. The Turks who also realized the importance of the rigge, reinforced it immediately with three infantry divisions, mainly its key position, the hill of Tel Khuweilfeh. $\vec{a}$

For five very hot and dry days and nights, the battle over Tel Khuweilfeh continued: series of local attackscand counter attacks inflicted heavy casualties on both siges, British and Turks. Tel Khuweilfeh was eventuqlly captured by British troops on November 7th. The 198th brigade paid a very high price in this battle: 36 officers and 584 men of other ranks were killed or wounded $(6+8)$.

Among the officers who were killed, on November during the battle on the ridge of Tel Khuweilfeh, w F tohn Fox-Russell, the MO of the 6th RWF, who had atergled many of the casualties.

John Fox-Russell was awarded posthumously to "for most conspicuous bravery displayed in action tht was killed. Captain Russell repeatedly went out to@्ञ to the wounded under murderous fire from snipes and machine guns, and in many cases where no other gieans were at hand, carried them in himself, although exhausted. He showed the highest possible valour."

In the obituary in the Lancet on February 2nd 19 written:

"He was a man of strong will and high ideals and l to play a leading part in any sphere of life." (2)

A real hero of military medicine.

REFERENCES

1. The Medical Victoria Crosses. Aldershot, 1983; p.

2. "Obituary of the War": John Fox-Russell. Lakiset 1918; I: 196.

3. "Casualties in the Medical Services". Brit M高 $J$ 1917; II: 701.

4. Wavell AP: The Palestine Campaigns. Constab \& Co., Ltd, London, 3rd Edition, 1932; pp. 76-80.

5. "The Honours List". Lancet 1917; II: 332.

6. DudLEY WARD CH: History of the 53rd (We Division 1914-1918; Western Mail Ltd, Cardiff, 1.827; p. 136.

7. Falls C (Editor). Military Operation Egyp \& Palestine. History of the Great War Series, HMSO, London, 1930; pp. 85-105.

8. Wavell AP: The Palestine Campaigns. Constablys \& Co., Ltd, London, 3rd Edition, 1932; pp. 131-137.

9. "The Honours List". Lancet 1918; I: 113. 